\title{
Worlds of William Penn
}

Eds. Andrew R. Murphy and John Smolenski

New Brunswick: Rutgers University Press, 2019

428 pages

ISBN: 1978801777

DOI: http://dx.doi.org/10.14713/njs.v5i1.178

William Penn's role in the founding of Pennsylvania is justly famous, but also significant was his role in the colonization of New Jersey. So it was appropriate for Rutgers University to sponsor a conference in 2015 where scholars from many disciplines presented papers on Penn's worlds. The editors chose the "worlds" title to pay homage while expanding the vision of a 1981 conference and publication marking the tri-centennial of the founding of Pennsylvania. ${ }^{1}$ None of the authors of that book or the editors of the Papers of William Penn contributed to this volume. ${ }^{2}$ Now we have the scholarship of a new generation exemplified by nineteen papers ably edited by Andrew R. Murphy, author of a biography of Penn and a study of his political theory, and John Smolenski, who wrote about creolization in early Pennsylvania.

Penn's attempt to combine imperialism with the creation of a secure peaceful society is an underlying theme of the articles on Ireland, religious liberty, Native Americans, and Quakerism. Several essays stress the formative influence of Penn's experiences in Ireland on his view of British colonization and shaping his later policies. Marcus Gallo examines William Petty's work surveying Irish lands that allowed more accurate titles and also enabled the English to seize more property. Admiral Penn and William both sought to secure and profited from the expropriated Irish lands. Gallo argues that the centralized control of Pennsylvania land sales followed the model established by Petty and was designed to end conflicts over land and foster orderly settlement. Audrey Horning describes that debate among the English whether the best way to rule Ireland was

\footnotetext{
${ }^{1}$ Richard Dunn and Mary Dunn, eds. World of William Penn (Philadelphia: University of Pennsylvania Press, 1986).

${ }^{2}$ Full disclosure, I wrote one of the twenty articles in World of William Penn.
} 
by coercion or conciliation. Penn became friends with members of the Boyle and Gookin families who advocated using persuasion to create a common culture. Horning sees this as influencing Penn's dealing with the Lenape. ${ }^{3}$ Patrick Cecil stresses Penn's knowledge of military force gained in Ireland, but later tempered by his Quakerism in prompting him to create "security communities" in West Jersey and Pennsylvania in dealing with native Americans, supporting religious liberty, and implementing liberal naturalization policies. Murphy argues that conflicts in Ireland and renewed persecution in England occasioned Penn's most complete defense of religious liberty, The Great Case of Liberty of Conscience. Penn believed that freedom to worship would end religious conflict and thereby strengthen the state and create prosperity. Scott Sowerby explains Penn's support of James II as designed to create a Magna Charta of religious liberty that would bring stability to England.

Creating successful colonies required dealing with existing inhabitants and attracting new ones. Michael Goode shows how the Lenape had established a modus vivendi in the Delaware River Valley involving power, diplomacy, trade, and good will before Penn had arrived. Evan Haefeli describes policies of religious freedom in New York, Rhode Island, New Jersey, and the Carolinas before 1680 and finds Pennsylania not pioneering but as a conservative continuation of this emphasis. Patrick Erben sees Penn's Quakerism as similar to pietism and shows how his religious journeys on the continent established a network that attracted German sectarians. Francis Daniel Pastorius and later Christopher Saur helped create the mythic Penn as founding father. Elizabeth Milroy analyses Penn's image and how it was used from his death until the creation of the monument on Philadelphia's city hall. The distance between a restless Penn, almost an itinerant, and his later reputation is the theme of Catherine Roeber. Alexander Mazzaferro

\footnotetext{
${ }^{3}$ Robert Boyle, most famous as a scientist, and Daniel Gookin sought a conciliatory policy for native Americans in Massachusetts.
} 
describes John Winthrop and William Penn as caught between a desire to preserve traditional societies, but willing to use "empirical" political science to adjust to new conditions. For Shuichi Wanibuchi, Penn's imperial vision required "improvement" of the new land that would be brought about by scientific methods of agriculture. The early maps of Pennsylvania, analyzed by Emily Mann, show Penn's imperial grasp, marketing savvy, and neglect of settlements of native Americans.

Articles that deal more with the "worlds" rather than Penn are Sarah Smith's discussion of religion in the Massachusetts Bay revolution against Edmund Andros in 1689, and Adrian Weimer's account of the reasons the government of Charles II viewed suspiciously Quaker declarations of loyalty. This is also true of Rachel Monroy's analysis of why early Quakers could convert so many Puritans in the American colonies and West Indies.

A fundamental issue for all scholars of William Penn is how he reconciled his different roles as Quaker, landowner, aristocrat, proprietor, politician, and adviser to James II. Perhaps inadvertently, several articles here point to a solution: Penn believed that benevolent government, good laws, a moral industrious people, consultation with indigenous peoples, and religious liberty would create a peaceful orderly society. So his vision of what Friends would later call the peace testimony would allow him to rule, prosper, and create a utopia. Unfortunately for him, it did not work that way in West Jersey, or Pennsylvania.

This volume supplements more than supersedes the earlier World of William Penn. Still, there are surprising omissions. Catie Gill's treatment of Penn's history of early Friends created as a preface to George Fox's Journal and Elizabeth Sauer on the reputation in the nineteenth century of writings by Milton, Bunyan, and Penn are the only discussions of religious writings. There is no treatment of Penn as theologian or moralist or his dealing with other Quakers in England. The 
history and politics of West Jersey and Pennsylvania are also slighted and there is not even a citation of the Biographical Dictionary of Pennsylvania Legislators. So although being appreciative for this book of thoughtful articles, we should look forward 30 years for an anthology entitled: The Old and New Worlds of William Penn.

\section{J. William Frost}

Swarthmore College 